\title{
E-Government Policy, Leadership Commitment, Apparatus Resources Development, and Their Implications on Public Service Performance
}

\author{
Hardiyansyah Hardiyansyah ${ }^{1, *}$, Koesharijadi Koesharijadi ${ }^{2}$, Muhamad Akbar ${ }^{3}$ \\ ${ }^{1}$ Management Department, Universitas Bina Darma, Palembang 30139, Indonesia/STIE Serelo Lahat \\ ${ }^{2}$ STIE Mitra Indonesia, Daerah Istimewa Yogyakarta 55172, Indonesia \\ ${ }^{3}$ Computer science, Universitas Bina Darma, Palembang 30139, Indonesia \\ *Corresponding author. Email: hardiyansyah@binadarma.ac.id
}

\begin{abstract}
This study aims to examine the implementation of e-government policies, leadership commitment, and the development of state apparatus as human resources and their implications on the performance of public services in the City Government of Lubuklinggau. Data were collected through questionnaires of 249 state employees in Lubuklinggau and analyzed through Multiple Regression Analysis. The results reveal that simultaneously and partially the implementation of e-government policies, leadership commitment, and state employees development significantly influence the performance of public services in the City Government of Lubuklinggau.
\end{abstract}

Keywords: e-government, commitment, human resources development, public service performance

\section{INTRODUCTION}

In general, public services in South Sumatra are substandard. The advent of law No. 25 The year 2009 concerning public services is unable to guarantee quality improvement. After ten years of implementing the policy, multitude of complaints and other problems still occur. Of the regions in South Sumatra, one of which is in the spotlight for unsatisfactory public service performance is the City of Lubuklinggau. These predicaments might be caused by several factors such as low enforcement of egov policy application, deficient leadership commitment, and ineffectual apparatus resources development.

Based on the explanation above, this study aims to investigate the effects of e-gov policy, leadership commitment, and apparatus resources development on the performance of public services in the City Government of Lubuklinggau. As such, it proposes a research question as follows: do e-gov policy implementation, leadership commitment, and apparatus resources development simultaneously and partially affect the performance of public services in the City Government of Lubuklinggau? The findings of this study offer substantial contributions both for the government and public in Lubuklinggau. In particular, for the government officials that have been elected from the previous election, the results of this research can be used to enhance public service performance. When the local residents benefit from the actual improvement, they will put more trust in the officials they have voted. Consequently, the Mayor of Lubuklinggau and other state offices heads have higher prospects of being re-elected in the ensuing election. The findings are also beneficial for the public themselves. The amelioration of public services performance will increase their efficacy and efficiency when dealing with governmental business and administration (e.g., trade licensing, tax payment, vehicle registration). This, in the end, will advance community welfare.

\section{LITERATURE REVIEW}

\subsection{E-Government}

The term 'E-Government' or often abbreviated as e-gov can be interpreted as a collection of concepts for all actions in the public sector (both at the Central and Regional Government levels), involving information and communication technology in order to optimize the efficiency, efficacy, and transparency of the public service processes [1]. In general, e-gov can be defined as an information management system and internet-based services provided by governments for the public. E-gov allows governments to develop various services to enhance their performance. E-gov also enables public to have active roles when dealing with governmental business and administration. For instance, public can independently register for licensing, monitor settlement processes, and access other public services. With the utilization of the internet and technology, all of these are accessible anywhere and anytime [2].

E-gov is empirically evident to have an influence on government performance. In their research, Kurniasih et al. demonstrated that the implementation of e-gov policies has 
a significant effect as much as $54.85 \%$ on the performance of the state employees in the City of Cimahi. Although the figure is relatively moderate, the application of e-gov policies is still one of dominant factors in determining the government officials performance [3].

\subsection{Leadership Commitment}

Leadership plays a significant role in achieving organizational goals [4]. Excellent leadership guides and motivates subordinates. Concurrently, it also enhances the efficacy and efficiency of its institution. These eventually improve performance and promote success. In regard to this, Davis studied the common traits of exceptional leaders. From the findings, he stated that these leaders are: (a) more intelligent relative to those being led; (b) mature, emotionally stable, socially active, keen to respect and be respected; (c) self-motivated and driven for achievement; and (d) passionate for human relations. According to the research in Ohio University and Michigan University, competent leaders are nurturing and instead of productionoriented they are employee-oriented [5].

Specifically for the public sector, empirical studies have proven the substantial contribution of leadership commitment. In his research, Hardiyansyah [6] \& Hardiyansyah and Mukran [7] concluded the successful implementation of policies in waste management and cleanliness in the City of Palembang is determined by communication, implementors' attitudes, resources, and bureaucracy structure. These four factors will perform satisfactorily only when supported by 'leadership commitment.' In this matter, the leader in the Mayor of Palembang and his commitment is to fully provide facilities and financial assistance (through Regional Government Budget) in order to make Palembang a clean city. In other research, Mutia in Aisyah et al. [8] supported the aforementioned findings. She explained that to augment public sector performance, organizational commitment from both employees and government leaders is required.

Furthermore, the Indonesian government has created a decree in an attempt to provide quality public services. It is Menpan-RB Regulation No. 24 Year 2014 concerning Guidelines for Management of Public Services. This directive, according to Deputy of Public Service in the Ministry of Administrative and Bureaucratic Reform (Kemenpan-RB) Mirawati Sudjono, only will be beneficial for public when assisted by leadership commitment. Leaders must guide and motivate their state employees to provide quick, convenient, and explicit procedures of public services. In particular, standard operating procedures and rules (e.g., for requirements and stages) must be straightforward to avoid confusion. Also, if processing time is needed, relevant government bureaux must distinctly state the duration and it must be reasonable. These eventually will be lucrative for the heads of offices. If they can provide excellent public services, campaigns are unnecessary for their future elections. A public that has benefited from the services will deem the leaders are credible and consequently they will vote for them.

\subsection{Apparatus Resources Development}

In her study in the State Employment Office of East Kalimantan Province, Findarti found that the development of human resources has an influence of $31 \%$ on the performance of employees. Human resources development involves the aspects of knowledge, skills, and attitudes [9]. Knowledge, both general and specific relating to the implementation of a task, is capable of determining the success of the task. Knowledgeable employees are productive and efficient. On the other hand, those who acquire less comprehension will unnecessarily exhaust their organization's time, materials, and other resources. These wastes will increase the cost of achieving organizational goals. Or worse, they will cause total failure.

Similarly, employees' skills pertinent to their fields contribute substantially to their level of performance. The expertise can materialize in multifarious forms. For instance, the IT staffs must be able to operate a computer, run relevant software, and keep themselves on track with the fast-changing technology industry. Also, the employees in the health department should hold the ability to detect hazardous food. Further, apart from the aforementioned, employees should be able to master soft skills. These can include speech, leadership, and customer service skills.

Additionally, personnel's attitudes also can influence the performance of an organization. Employees should apprehend how to properly interact with their leaders, peers, and customers. They also should positively accept and act on the implementation of policy and culture. Employees' negative attitudes could be disastrous for an institution. It has the prospect to cause tension and stress. On the other hand, positive attitudes can construct a welcoming and supportive work environment. As a result, it can improve productivity.

Therefore, to improve employees' performance, it is crucial for an organization to focus on human resources development. This can be done by providing continuous education and training. The effort is expected to produce human resources with participatory excellence that develops the principles of fair competition to seek preeminent methods, processes, and results [10]. In the more extensive scale, it will prepare Indonesian state employees and government in general in competing against globalization.

\subsection{Service Performance}

Performance is the only reliable variable to measure the success, or failure, of an organization. To study it, a comprehensive understanding is needed. In an organization, there are three objectives. They are 
organized units and employees objectives. Accordingly, there are three types of performance. They are organization, units, and employees performance. Every objective is related from one to another. When organization objectives are understandable, it will be facile to comprehend and formulate the remaining. Likewise is the performance.

Researchers have studied the performance of several departments in the public sector. In her study, Herdinawati [11] examined the performance of employees in the City Government of Surabaya. The initiative emerged due to the absence of reward and punishment systems and poor performance. The study aimed to investigate three aspects, namely: (a) the implementation of e-performance in the City Government of Surabaya; (b) employees' performance before and after the application of eperformance programme; and (c) the factors that hindered the implementation of the e-performance programme. The findings indicated that all levels of officials implemented the e-performance programme since 2011. Additionally, after the implementation of the programme, the employees' performance improved. The results also revealed two factors that inhibited the programme. First, the staffs in the Program Development Department lacked in information technology skills that caused ineffectiveness in managing employee activities. Second, there was a misuse of employee accounts that negatively affected other parties. Lastly, the study found that the Mayor Regulation as the legal basis for the implementation of e-performance supported the programme. The money and technology grants enhanced the performance of employees in the Program Development Department in the City Government of Surabaya.

Furthermore, Ariany and Putera evidenced moderate level of service performance in two SKPDs in the City Government of Pariaman. For the Integrated Licensing and Investment Services Office (KP2TPM), the service given is satisfactory. However, the SKPDs pertinent to licensing in this department lack in coordination. For the Civil Registry Office, although the service is acceptable, the standard operating procedures (SOPs) is inexplicit. As a result, state employees fail to provide excellent services. Thus, it is necessary to develop the apparatus resources to advance services and coordination between SKPDs related to licensing [12] and [13].

\section{RESEARCH METHODOLOGY}

This quantitative research employs multiple regression analysis methods. The data are primary and derived from questionnaires and field observations. The respondents are state employees (ASN) based in Lubuklinggau from the One-Stop Integrated Investment and Services Office (DPMPTSP); Regional Income Office; Civil Registry Service Office; and City Planning Office as well as SubDistrict Office. This study distributed 300 questionnaires and received 249 responses.

\section{RESULTS AND DISCUSSION}

Based on the responses from the respondents, the following information was obtained:

\subsection{Regression Analysis Results}

Table 1 Deskriptive statistics

\begin{tabular}{|l|r|r|r|}
\hline & \multicolumn{1}{|c|}{ Mean } & Std. Deviation & \multicolumn{1}{l|}{ N } \\
\hline Public Service & 3.8487 & .59505 & 249 \\
Performance & 3.7905 & .62563 & 249 \\
E-Government Policy & 4.0558 & .58876 & 249 \\
Commitment of Leader & 3.9423 & .57634 & 249 \\
Development of & & & \\
Apparatus Resources & &
\end{tabular}

From a scale of 5, the average perception of respondents of the variable Public Service Performance (PSP) is 3.84, the average perception of respondents of the variable EGovernment Policy (E-Gov) is 3.79, the average perception of respondents of the variable Commitment of Leader (Commit) is 4.06, and the average perception of respondents of the variable Development of Apparatus Resources (DAR) of 3.94.

Table 2 Correlations

\begin{tabular}{|c|c|c|c|c|c|}
\hline & & $\begin{array}{l}\text { Public Senvice } \\
\text { Performance }\end{array}$ & $\begin{array}{c}\text { E. } \\
\text { Gorernment } \\
\text { Policy }\end{array}$ & $\begin{array}{l}\text { Commitment } \\
\text { of Leader }\end{array}$ & $\begin{array}{l}\text { Development } \\
\text { of Apparatus } \\
\text { Resources }\end{array}$ \\
\hline \multirow[t]{4}{*}{ Pearson Correlation } & $\begin{array}{l}\text { Public Service } \\
\text { Pertormance }\end{array}$ & 1.000 & .734 & .560 & .748 \\
\hline & E-Government Policy & .734 & 1.000 & 568 & .764 \\
\hline & Comnitoment of Leader & 560 & .569 & 1.000 & 527 \\
\hline & $\begin{array}{l}\text { Development of } \\
\text { Apparatus Resources }\end{array}$ & .749 & .764 & .527 & 1.000 \\
\hline \multirow[t]{4}{*}{ Sig (1-tailed) } & $\begin{array}{l}\text { Public Service } \\
\text { Performance }\end{array}$ & & .000 & .000 & .000 \\
\hline & E-Government Policy & .000 & & .000 & .000 \\
\hline & Commitement of Leader & .000 & .000 & & .000 \\
\hline & $\begin{array}{l}\text { Development of } \\
\text { Apparatus Resourtes }\end{array}$ & .000 & .000 & .000 & \\
\hline \multirow[t]{4}{*}{$\mathrm{N}$} & $\begin{array}{l}\text { Public Senvice } \\
\text { Pefformance }\end{array}$ & 248 & 249 & 248 & 249 \\
\hline & E-Government Policy & 249 & 249 & 249 & 249 \\
\hline & Commitoment of Leader & 249 & 249 & 249 & 249 \\
\hline & $\begin{array}{l}\text { Development of } \\
\text { Apparatus Resources }\end{array}$ & 249 & 249 & 249 & 249 \\
\hline
\end{tabular}

There is a moderate relationship between Public Service Performance (PSP) with E-Government Policy (E_Gov), Commitment of Leader (Commit), and Development of Apparatus Resources (DAR). Statistically, there is a significant relationship of Public Service Performance (PSP) with E-Government Policy (E_Gov), Commitment of Leader (Commit), and Development of Apparatus Resources (DAR) as the obtained p-value (Sig.) is less than $5 \%$. In addition, there are significant relationships among independent variables but statistically, the relationships fail to show any deviation from the multicollinearity assumption. 
Table 3 Variables entered

\begin{tabular}{|c|c|c|c|}
\hline Model & $\begin{array}{c}\text { Variables } \\
\text { Entered }\end{array}$ & $\begin{array}{l}\text { Variables } \\
\text { Removed }\end{array}$ & Method \\
\hline 1 & $\begin{array}{l}\text { Development } \\
\text { or Apparatus } \\
\text { Resources. } \\
\text { Commitment } \\
\text { of Leader. E- } \\
\text { Government } \\
\text { Policyb }\end{array}$ & & Enter \\
\hline
\end{tabular}

Table 4 Model summary

\begin{tabular}{|l|l|r|r|r|}
\hline Model & $\mathrm{R}$ & $\mathrm{R}$ Square & $\begin{array}{c}\text { Adjusted R } \\
\text { Square }\end{array}$ & $\begin{array}{c}\text { Std. Error of } \\
\text { the Estimate }\end{array}$ \\
\hline 1 & $.800^{\mathrm{a}}$ & .639 & .635 & .35958 \\
\hline
\end{tabular}

a. Predictors: (Constant), Development of Apparatus Resources, Commitment of Leader, E-Government Policy

The coefficient of determination value (R2) of 0.635 indicates that the model obtained can explain variations in existing data of $63.5 \%$. The strength of this model is relatively sufficient as it is only for hypothesis testing instead of prediction.

Table 5 Anova $^{\mathrm{a}}$

\begin{tabular}{|c|c|c|c|c|c|c|}
\hline Mode & & $\begin{array}{l}\text { Sum of } \\
\text { Squares }\end{array}$ & df & Mean Square & $\mathrm{F}$ & Sig. \\
\hline \multirow[t]{3}{*}{1} & Regression & 56.136 & 3 & 18.712 & 144.721 & $.000^{b}$ \\
\hline & Residual & 31.678 & 245 & .129 & & \\
\hline & Total & 87.814 & 248 & & & \\
\hline
\end{tabular}

a. Dependent Variable: Public Service Performance

\section{b. Predictors: (Constant), Development of Apparatus Resources, Commitment of Leader, E- Government Policy}

As a result of simultaneous testing, the F-test statistic value is as much as 144.72 with a p-value (Sig.) of 0,000 , which is less than 5\%. This shows that there is a significant effect between the three independent variables simultaneously on the dependent variable (PSP).

Table 6 Coefficients ${ }^{\mathrm{a}}$

\begin{tabular}{|c|c|c|c|c|c|c|}
\hline \multirow[b]{2}{*}{ Model } & & \multicolumn{2}{|c|}{ Unstandardiced Coeficients } & \multirow{2}{*}{$\begin{array}{c}\begin{array}{c}\text { Standardiced } \\
\text { Coefficients }\end{array} \\
\text { Beta }\end{array}$} & \multirow[b]{2}{*}{$t$} & \multirow[b]{2}{*}{ Sig. } \\
\hline & & $B$ & Stid Error & & & \\
\hline \multirow[t]{4}{*}{1} & (Constant) & .339 & .181 & & 1.874 & .062 \\
\hline & E-Government Policy & .310 & .059 & .326 & 5.227 & .000 \\
\hline & Commitment of Leader & .154 & .048 & .153 & 3220 & .001 \\
\hline & $\begin{array}{l}\text { Development of } \\
\text { Apparatus Resources }\end{array}$ & .433 & .062 & .420 & 6.947 & .000 \\
\hline
\end{tabular}

a. DependentVariable: Public Serice Performance

The results of partial testing are as follows:

1. There is a significant positive effect from E-Gov as much as $10.6 \%$ on PSP if other factors are considered constant. This means that if E-Gov increases, the PSP will follow.
2. There is a significant positive effect from Commit as much as $2.3 \%$ on PSP if other factors are considered constant. This means that if Commit increases, the PSP will follow.

3. There is a significant positive effect from DAR as much as $17.6 \%$ on PSP if other factors are considered constant. This means that if DAR increases, the PSP will follow.

\subsection{Regression Coefficient Test Results}

The results of calculations of the multiple linear regression coefficients present the regression equation as follows: $\mathrm{Y}$ $=0.339+0.310 \mathrm{X} 1-0.154 \mathrm{X} 2+0.433 \mathrm{X} 3+\mathrm{e}$

The equation above can be interpreted as a constant value of 0.339 indicates that if the value of E-Government Policy Implementation (X1), Leadership Commitment (X2), and Development of Apparatus Resources (X3) is equal to zero, or in other words, if there is no EGovernment Policy Implementation, Leadership Commitment, and Development of Apparatus Resources then the value of Public Service Performance is 0.339 statistical unit value.

The coefficient value of $\mathrm{X} 1=0.310$ states that for each addition of 1 statistical unit value of E-Government Policy Implementation, 0.310 statistical unit value of Public Service Performance will increase, given that Leadership Commitment (X2) and Development of Apparatus Resources (X3) are constant.

The coefficient value of $\mathrm{X} 2=-0.154$ states that for each addition of 1 statistical unit value of Leadership Commitment, 0.154 statistical unit value of Public Service Performance will decrease, given that E-Government Policy Implementation (X1) and Development of Apparatus Resources (X3) are constant.

The coefficient value of $\mathrm{X} 3=0.433$ states that for each addition of 1 statistical unit value of Development of Apparatus Resources, 0.433 statistical unit value of Public Service Performance will decrease, given that EGovernment Policy Implementation (X1) and Leadership Commitment (X2) are constant.

Additionally, the t-test is needed to partially measure the significant effects of E-Government Policy Implementation, Leadership Commitment, and Development of Apparatus Resources on Public Service Performance. The findings show that sig $=0,000$ and $\alpha=$ 0.05 . The sig value is smaller than the value of $\alpha$ for all of the variables. This means that E-Government Policy Implementation has a significant effect on the Performance of Public Services, Leadership Commitment has a significant effect on the Performance of Public Services, and Development of Apparatus Resources has a significant effect on the Performance of Public Services.

\section{CONCLUSION}

The results of this study reveal that, simultaneously and partially, the implementation of e-government policies, 
leadership commitment, and apparatus resources development have significant effects on the performance of public services in the City Government of Lubuklinggau. This implies that as long as the City Government of Lubuklinggau properly manages and enhance their implementation of e-government policies, leadership commitment, and apparatus resources development, they will produce quality public service performance.

\section{ACKNOWLEDGMENT}

This research is a grant of Basic Excellence Higher Education Institution Research (PDUPT) funded by the Directorate of Research and Community Service of Ministry of Research, Technology and Higher Education in accordance with the Research Contract of Budget Year 2019, DIPA No. 042.06.401516/2019. Regarding this, we would like to express our deepest appreciation. We also would extend our gratitude to all the ASNs in the City Government of Lubuklinggau for their willingness to become our respondents. Lastly, we also thank the field, survey, and statistical data processing staffs.

\section{REFERENCES}

[1] Kurniawan, T., "Hambatan dan Tantangan dalam Mewujudkan Good Government di Indonesia." http://publications-tk.blogspot.com/ (accessed date 27/4/2017).

[2] Abidin, Z., Electronic Government dan Penerapannya di Kabupaten Takalar. Yogyakarta: MAP-UGM, 2000.

[3] Kurniasih, D., Fidowaty, T. \& Sukaesih, P., "Pengaruh Implementasi Kebijakan EGovernment Terhadap Kinerja Aparatur Kota Cimahi." Sosiohumaniora, vol. 15, no. 1, pp. 610, Maret 2013.

[4] Siagian, S. P., Manajemen Sumber Daya Manusia. Bumi Aksara. Jakarta, 2005.

[5] Davis, K., Human Relation at Work. Grown Hill Book Co Inc, Kasagata, Co. Ltd. Tokyo, 2002.

[6] Hardiyansyah, "Model Implementasi Kebijakan Publik dalam Pengelolaan Sampah dan Kebersihan Kota Palembang." Jurnal Mimbar, vol. 30 no.1, pp. 108-117, Juni 2015.

[7] Hardiyansyah and Mukran, "The Model Strategy of Improvement of the Public Services Quality and Optimization of the District Own Source
Revenue to the Government of Palembang, Indonesia." The Social Sciences, vol. 11, No. 22, pp. 5496-5500, June 2016.

[8] Aisyah, S., Karmizi dan Savitri, E., "Pengaruh Good Governance, Gaya Kepemimpinan, Komitmen Organisasi dan Budaya Organisasi Terhadap Kinerja Pemerintah Daerah (Studi Pada Pemerintah Daerah Kabupaten Kampar)." JOM FEKON, vol. 1 no. 2, pp. 1-16, Februari 2014.

[9] Findarti, F. R., "Pengaruh Pengembangan Sumber Daya Manusia Terhadap Kinerja Pegawai pada Kantor Badan Kepegawaian Daerah Provinsi Kalimantan Timur.” eJournal Ilmu Administrasi Bisnis, vol. 4 no. 4, pp. 937946 ISSN 2355-5408, ejournal.adbisnis.fisipunmul.ac.id, November 2016.

[10] Satar, M., "Pengembangan SDM Indonesia Unggul Menghadapi Masyarakat Kompetitif Era Globalisasi." Jurnal Mimbar, vol. 18 no. 4, pp. 429-442, Februari 2002.

[11] Herdinawati, B., "Analisis Kinerja Pegawai Negeri Sipil Pemerintah Kota Surabaya melalui Electronic Performance (Studi Penerapan EPerformance pada Bagian Bina Program Pemerintah Kota Surabaya)." Jurnal Administrasi Publik, vo. 2 no. 5, pp. 1-7. Maret 2014.

[12] Ariany, R. \& Putera, R. E., "Analisis Kinerja Organisasi Pemerintah dalam Memberikan Pelayanan Publik di Kota Pariaman." Jurnal MIMBAR, vol. 29 no. 1, pp. 33-40, Juni 2013

[13] Hardiyansyah and Hardiyansyah, "Performance Analysis of the Autonomous Regional Government Through the Public Satisfaction Survey: A Case Study on the Government of Ogan Komering Ilir, South Sumatra, Indonesia." Research Journal of Applied Sciences, vol. 11, no. 10, pp. 997-1001, 2016. 